\title{
The effect of feeding a diet naturally contaminated with deoxynivalenol on production traits and selected biochemical indicators of broiler chickens
}

\author{
Márta Erdélyi ${ }^{1}$, Mária Weber ${ }^{2}, K_{\text {risztián Balogh }}^{1,3}$, Zsolt Ancsin $^{1}$, Miklós Mézes $^{1}$ \\ ${ }^{1}$ Department of Nutrition, ${ }^{2}$ Department of Pig and Small Animal Breeding, Szent István University, \\ Gödöllö, Hungary \\ ${ }^{3}$ Research Group of Animal Breeding and Hygiene, Faculty of Animal Science, University of Kaposvár, \\ Kaposvár, Hungary \\ Received August 18, 2010 \\ Accepted April 6, 2011
}

\begin{abstract}
The effect of feeding a diet naturally contaminated with deoxynivalenol (DON) (0-21 days: $1.50 \mathrm{mg} \cdot \mathrm{kg}^{-1}$; 22-39 days: $\left.1.54 \mathrm{mg} \cdot \mathrm{kg}^{-1}\right)$ was studied in 40 broiler chickens. Birds were divided into two groups fed a control diet and a diet contaminated with DON ( $n=20$ in each). Feed intake was measured daily and individual live weight weekly; daily weight gain and feed to gain ratio were calculated. Five animals from each group were euthanized on days 21 and 39 when blood (blood plasma and red blood cell haemolysates) and liver samples were collected. Concentration of triglyceride, uric acid and glucose and activities of ALT, AST and LDH were measured in blood plasma. Indicators of lipid peroxide and glutathione redox status, malondialdehyde and reduced glutathione concentration and glutathione-peroxidase activity were measured in blood plasma, red blood cell haemolysates and liver homogenates. The low dose of DON did not cause difference in the production traits, but caused significantly lower concentration of uric acid and glucose, and significantly higher concentration of triglyceride in blood plasma on day 21. Enzyme activities in blood plasma did not differ significantly between the treatment groups. Among the markers of lipid peroxide and glutathione redox status, malondialdehyde content was significantly higher in liver homogenate on day 21 in the group fed with DON contaminated diet, but reduced glutathione content and glutathione peroxidase activity did not differ significantly between the treatment groups. The results showed that diet contaminated even with a low content of deoxynivalenol caused alterations in selected biochemical indicators of blood and liver of broiler chicken.
\end{abstract}

Biochemical markers, malondialdehyde, glutathione, glutathione peroxidase

Moulds produce different mycotoxins that have importance in farm animal nutrition because of their widespread occurrence and diversity (Lees on et al. 1995). Among various mycotoxins, those produced by Fusarium moulds, such as deoxynivalenol (DON) are often found in feed ingredients even at high concentrations in different parts of the world under different environmental conditions (Jelinek et al. 1989).

The official recommendation in the European Union for the maximum DON content in the poultry feeds is $5 \mathrm{mg} \cdot \mathrm{kg}^{-1}$ (EU 2006). Additionally, Eriksen and Pettersson (2004) found that levels from $9 \mathrm{mg} \mathrm{DON} \cdot \mathrm{kg}^{-1}$ feed had negative effects in chickens, while no effect was found in chicken fed $5 \mathrm{mg}$ DON $\cdot \mathrm{kg}^{-1}$ feed, therefore they proposed a guideline value of $2.5 \mathrm{mg} \mathrm{DON} \cdot \mathrm{kg}^{-1}$ feed. However, in early experiments of Kubena et al. (1987, 1988) only moderate effects were found in production traits even at extremely high contamination levels of 16 or $18 \mathrm{mg} \mathrm{DON} \cdot \mathrm{kg}^{-1}$ feed. No significant effect was found on leukocytes using dietary level of up to $3 \mathrm{mg} \cdot \mathrm{kg}^{-1} \mathrm{DON}$, except for the attenuated phagocytic activity of granulocytes, and increased number of heterophils (Levkut et al. 2009). The same level of DON contamination resulted in alterations of clinical biochemical indicators in blood plasma, namely lower total protein and triglyceride content and higher alanineaminotransferase activity (Faixova et al. 2006). Feeding diet artificially contaminated with a low dose of DON (3.4 $\left.\mathrm{mg} \cdot \mathrm{kg}^{-1}\right)$ together with zearalenone demonstrated that this

Address for correspondence:

Miklós Mézes

Department of Nutrition, Szent István University

H-2103 Gödöllő, Páter Károly u. 1., Hungary
Phone: +3628410735

Fax: +3628410804

Email: Mezes.Miklos@mkk.szie.hu

http://www.vfu.cz/acta-vet/actavet.htm 
diet induces oxidative stress (Borutova et al. 2008). The biochemical mode of action of trichothecene mycotoxins on lipid peroxidation and antioxidant defence is not completely understood (Surai 2002; Weber et al. 2010), but marked changes were found even at low levels of contamination (Dersjant-Li et al. 2003).

The aim of the present study was to evaluate the effect of naturally contaminated feed with a low level of DON on some production traits, clinical biochemical indicators of blood, and on lipid peroxide and glutathione redox indicators in broiler chickens.

\section{Materials and Methods}

Animals and diets

A total of 40 one-day-old Hubbard cockerels were divided into two groups. One was fed a control diet $(\mathrm{C}, \mathrm{n}=20)$ and the other group a diet composed of $40 \%$ of maize naturally contaminated with deoxynivalenol and $60 \%$ of control diet $(\mathrm{DON}, \mathrm{n}=20)$. Nutrient content of the diets met the requirements for broiler chicken according to the Hungarian standards (Hungarian Feed Code 2004a) and was determined according to standard methods (Hungarian Feed Code 2004b). The feeding trial lasted for 39 days. Complete feeds were given in mash form in the first phase (days 1 to 21). The control diet contained $0.05 \mathrm{mg} \cdot \mathrm{kg}^{-1} \mathrm{DON}$; the contaminated diet contained $1.50 \mathrm{mg} \cdot \mathrm{kg}^{-1} \mathrm{DON}$. In the second phase (days 22 to 39) diets in mash form were fed with the same nutrient content, and had $0.06 \mathrm{mg} \cdot \mathrm{kg}^{-1}$ and $1.54 \mathrm{mg} \cdot \mathrm{kg}^{-1} \mathrm{DON}$, respectively (Table 1).

The content of DON in diets was measured by HPLC technique (Central Veterinary Institute, Budapest) according to the European Union directive (EU 2005).

Table 1. Nutrition and deoxynivalenol content of diet used for two groups (control and DON) of broiler chicken during two phases of feeding

\begin{tabular}{|c|c|c|c|c|}
\hline \multirow[t]{2}{*}{ Nutrient } & \multicolumn{2}{|c|}{$\begin{array}{c}\text { Phase } 1 \\
\text { (days } 1 \text { to } 21 \text { ) }\end{array}$} & \multicolumn{2}{|c|}{$\begin{array}{c}\text { Phase } 2 \\
\text { (days } 22 \text { to } 39 \text { ) }\end{array}$} \\
\hline & Control & DON & Control & DON \\
\hline Dry matter $\left(\mathrm{g} \cdot \mathrm{kg}^{-1}\right)$ & 898.80 & 897.40 & 897.10 & 895.60 \\
\hline Crude protein $\left(\mathrm{g} \cdot \mathrm{kg}^{-1}\right.$ d.m.*) & 196.37 & 199.13 & 197.03 & 198.23 \\
\hline Crude fat $\left(\mathrm{g} \cdot \mathrm{kg}^{-1} \mathrm{~d} . \mathrm{m}.\right)$ & 30.15 & 31.09 & 31.11 & 30.84 \\
\hline Crude fibre (g. $\mathrm{kg}^{-1}$ d.m.) & 23.59 & 23.07 & 24.02 & 23.88 \\
\hline Crude ash (g.kg-1 d.m.) & 62.97 & 68.98 & 63.92 & 67.45 \\
\hline Nitrogen free extract $\left(\mathrm{g} \cdot \mathrm{kg}^{-1} \mathrm{~d} \cdot \mathrm{m}.\right)$ & 686.92 & 677.74 & 683.92 & 679.60 \\
\hline Deoxynivalenol $\left(\mathrm{mg} \cdot \mathrm{kg}^{-1}\right)$ & 0.05 & 1.50 & 0.06 & 1.54 \\
\hline
\end{tabular}

* d.m. - dry matter; DON - deoxynivalenol

Production traits

Body weight measurements were made individually during the trial on a weekly basis. Feed intake was measured daily in each group and calculated per day and animal. Average daily weight gain and feed to gain ratio were calculated.

Sampling and measurement of biochemical indicators

Five animals from each group were euthanized on day 21 and 39, when dissection was carried out, and blood and liver samples were collected. Blood samples were stored at $+4{ }^{\circ} \mathrm{C}$, then the plasma was separated from the blood cells by centrifugation $(2500 \mathrm{~g}, 20 \mathrm{~min})$. Red blood cells were lysed with deionised water (ratio 1:9) and by freezing and thawing. Liver samples were homogenized in nine-fold volume of $0.65 \%(\mathrm{w} / \mathrm{v}) \mathrm{NaCl}$. The samples were stored at $-20^{\circ} \mathrm{C}$ until analysis.

Clinical biochemical indicators, such as concentration of triglyceride, uric acid and glucose and activities of alanine-aminotransferase (ALT), aspartate aminotransferase (AST) and lactate dehydrogenase (LDH) were determined by commercial enzymatic colorimetric diagnostic kits (Diagnosticum Ltd., Budapest).

For determination of malondialdehyde (MDA) concentration in the blood samples, the method of Placer et al. (1966) and in liver homogenates the method of Mihara et al. (1980) was used. Reduced glutathione (GSH) concentration was measured with the method of Sedlak and Lindsay (1968). Glutathione peroxidase (GSHPx) activity was measured with the method of Lawrence and Burk (1976). For determination of protein content in blood plasma and red blood cell haemolysates the biuret method was used (Weichselbaum 1948). In the $10,000 \mathrm{~g}$ supernatant fraction of liver homogenates total protein concentrations were determined according to the method of Lowry et al. (1951). 
Statistical methods

Statistical evaluation of the results was carried out by Student's 2-sample $t$-test after calculating the means and standard deviations (SD) with Statistic ${ }^{\mathrm{TM}} 4.0$ (Statsoft Inc. 1993) software.

The experiment was approved by the Animal Experimental Committee of the Faculty of Agricultural and Environmental Sciences of the Szent István University (2/2005).

\section{Results}

Production traits

There was no significant difference in the average body weight of birds during the trial between the control group and the group fed DON contaminated diet (Table 2). Feed intake was measured in each group daily and there was no significant difference between the groups (Table 3). Feed to gain ratio was calculated based on the average body weight and feed intake of the groups weekly (Table 4). Feeding DON contaminated diet did not cause differences in the average daily weight gain and feed to gain ratio during the growing period.

Table 2. Live weight of two groups of broiler chickens (g; mean $\pm \mathrm{SD}$ )

\begin{tabular}{lrrrrrrr}
\hline Day & 0 & \multicolumn{1}{c}{7} & \multicolumn{1}{c}{14} & \multicolumn{1}{c}{21} & \multicolumn{1}{c}{28} & \multicolumn{1}{c}{35} & 39 \\
\hline \multirow{2}{*}{ Control } & 41.64 & 125.00 & 319.77 & 665.23 & 1028.33 & 1508.75 & 1795.42 \\
& \pm 1.04 & \pm 19.52 & \pm 48.19 & \pm 103.86 & \pm 200.72 & \pm 292.36 & \pm 341.32 \\
\multirow{2}{*}{ DON } & 41.59 & 135.91 & 342.14 & 688.81 & 1111.36 & 1636.36 & 1906.91 \\
& \pm 0.72 & \pm 17.64 & \pm 59.99 & \pm 104.75 & \pm 203.75 & \pm 227.63 & \pm 233.09 \\
\hline
\end{tabular}

DON-deoxynivalenol

Table 3. Average daily feed consumption $\left(\mathrm{g} \cdot \mathrm{day}^{-1}\right.$ per animal) in two groups of broiler chickens

\begin{tabular}{ccr}
\hline Week & Control & DON \\
\hline 1 & 16.75 & 18.05 \\
2 & 49.81 & 64.95 \\
3 & 95.91 & 90.88 \\
4 & 175.71 & 186.75 \\
5 & 192.26 & 212.47 \\
6 & 222.71 & 201.14 \\
\hline
\end{tabular}

DON-deoxynivalenol Enzymes, such as LDH, AST and ALT, which reflect tissue damage did not show significant differences between the two groups either on day 21 or day 39.

Table 4. Average daily weight gain and feed conversion ratio in the different phases of growing period in two groups of broiler chickens

\begin{tabular}{|c|c|c|c|c|c|c|}
\hline Week & 1 & 2 & 3 & 4 & 5 & 6 \\
\hline \multicolumn{7}{|c|}{ Average daily weight gain (g/bird) } \\
\hline Control & 11.91 & 27.82 & 49.35 & 51.87 & 68.63 & 71.67 \\
\hline DON & 13.47 & 29.46 & 49.52 & 60.36 & 75.00 & 67.64 \\
\hline \multicolumn{7}{|c|}{ Feed to gain ratio (g feed consumption/g weight gain) } \\
\hline Control & 1.41 & 1.79 & 1.94 & 3.39 & 2.80 & 3.11 \\
\hline DON & 1.34 & 2.20 & 1.84 & 3.09 & 2.83 & 2.97 \\
\hline
\end{tabular}

DON-deoxynivalenol
Biochemical indicators

Significant changes were found in some blood plasma biochemistry indicators at samplings on days 21 and 39 (Table 5). The uric acid content, which reflects the protein metabolism, and glucose content in blood plasma was significantly lower in the DON group compared to the control on day 21 , but this difference was not observed on day 39. In contrast, triglyceride content of blood plasma was significantly higher in DON group on day 21 compared to the control. 
Table 5. Effect of diet contaminated with deoxynivalenol on selected blood plasma biochemical indicators of broiler chicken (mean $\pm \mathrm{SD})$

\begin{tabular}{|c|c|c|c|c|c|c|c|}
\hline & $\begin{array}{c}\text { Protein } \\
\left(\mathrm{g} \cdot \mathrm{l}^{-1}\right)\end{array}$ & $\begin{array}{c}\mathrm{TG} \\
\left(\mathrm{mmol} \cdot \mathrm{l}^{-1}\right)\end{array}$ & $\begin{array}{l}\text { Uric acid } \\
\left(\mathrm{mmol} \cdot \mathrm{l}^{-1}\right)\end{array}$ & $\begin{array}{c}\text { Glucose } \\
\left(\mathrm{mmol} \cdot \mathrm{l}^{-1}\right)\end{array}$ & $\begin{array}{c}\mathrm{LDH} \\
\left(\mu \mathrm{kat} \cdot 1^{-1}\right)\end{array}$ & $\begin{array}{c}\text { AST } \\
\left(\mu \mathrm{kat} \cdot 1^{-1}\right)\end{array}$ & $\begin{array}{c}\text { ALT } \\
\left(\mu \mathrm{kat} \cdot \cdot^{-1}\right)\end{array}$ \\
\hline & Day 21 & & & & & & \\
\hline \multirow{2}{*}{ Control } & 28.28 & $0.69^{a}$ & $140.11^{b}$ & $35.44^{\mathrm{b}}$ & 16.08 & 2.22 & 0.49 \\
\hline & \pm 6.12 & \pm 0.19 & \pm 48.10 & \pm 12.17 & \pm 6.07 & \pm 0.50 & \pm 0.18 \\
\hline \multirow{3}{*}{ DON } & 31.22 & $0.89^{\mathrm{b}}$ & $82.20^{\mathrm{a}}$ & $15.96^{\mathrm{a}}$ & 18.06 & 2.12 & 0.39 \\
\hline & \pm 4.90 & \pm 0.23 & \pm 20.32 & \pm 3.94 & \pm 5.55 & \pm 1.00 & \pm 0.16 \\
\hline & Day 39 & & & & & & \\
\hline \multirow{2}{*}{ Control } & 38.52 & $2.28^{\mathrm{b}}$ & 67.26 & 15.82 & 11.96 & 2.42 & 0.37 \\
\hline & \pm 4.67 & \pm 1.06 & \pm 23.68 & \pm 6.63 & \pm 8.14 & \pm 0.78 & \pm 0.18 \\
\hline \multirow{2}{*}{ DON } & 40.12 & $0.57^{\mathrm{a}}$ & 68.90 & 16.21 & 19.91 & 3.36 & 0.38 \\
\hline & \pm 6.83 & \pm 0.29 & \pm 25.22 & \pm 5.64 & \pm 7.53 & \pm 1.52 & \pm 0.16 \\
\hline
\end{tabular}

a,b Different superscripts in the same column mean significant difference at $P<0.05$ level

DON-deoxynivalenol; TG-triglyceride; LDH-lactate dehydrogenase; AST-aspartate aminotransferase;

ALT-alanine aminotransferase

\section{Lipid peroxide and glutathione redox status of blood and liver}

Malondialdehyde content which

Table 6. Effect of feeding DON contaminated diet on malondialdehyde and reduced glutathione content and glutathione peroxidase activity of blood plasma (mean $\pm \mathrm{SD}$ )

\begin{tabular}{llcc}
\hline & $\begin{array}{c}\text { MDA } \\
\left(\mu \mathrm{mol} \cdot \mathrm{l}^{-1}\right)\end{array}$ & $\begin{array}{c}\text { GSH } \\
\left(\mathrm{mmol} \cdot \mathrm{g}^{-1} \text { protein }\right)\end{array}$ & $\begin{array}{c}\text { GSHPx } \\
\left(\mu \mathrm{kat} \cdot \mathrm{l}^{-1}\right)\end{array}$ \\
\hline Control & $\begin{array}{l}\text { Day } 21 \\
6.03 \pm 2.88\end{array}$ & $6.29 \pm 1.28$ & $8.63 \pm 1.50$ \\
DON & $6.97 \pm 1.49$ & $5.72 \pm 1.02$ & $7.64 \pm 1.25$ \\
& Day 39 & & \\
Control & $7.12 \pm 1.94$ & $4.80 \pm 0.69$ & $6.96 \pm 1.63$ \\
DON & $7.05 \pm 1.25$ & $4.74 \pm 0.68$ & $6.34 \pm 1.92$ \\
\hline
\end{tabular}

$\overline{\text { DON-deoxynivalenol; MDA-malondialdehyde; GSH-reduced }}$ glutathione; GSHPx-glutathione peroxidase

Table 7. Effect of diet contaminated with deoxynivalenol on malondialdehyde and reduced glutathione content and glutathione peroxidase activity of red blood cell haemolysate $($ mean $\pm \mathrm{SD})$ in broiler chicken

\begin{tabular}{|c|c|c|c|}
\hline & $\begin{array}{c}\text { MDA } \\
(\mu \mathrm{mol} \cdot 1-1)\end{array}$ & $\begin{array}{c}\text { GSH } \\
(\mathrm{mmol} \cdot \mathrm{g}-1 \text { protein })\end{array}$ & $\begin{array}{c}\text { GSHPx } \\
(\mu \mathrm{kat} \cdot 1-1)\end{array}$ \\
\hline & Day 21 & & \\
\hline Control & $7.92 \pm 0.78^{b}$ & $9.36 \pm 4.18$ & $6.26 \pm 2.10$ \\
\hline DON & $\begin{array}{l}6.60 \pm 0.73^{a} \\
\text { Day } 39\end{array}$ & $12.36 \pm 3.30$ & $6.59 \pm 1.85$ \\
\hline Control & $18.52 \pm 4.80^{b}$ & $10.33 \pm 1.81$ & $6.76 \pm 1.63$ \\
\hline DON & $12.33 \pm 3.76^{\mathrm{a}}$ & $10.75 \pm 2.54$ & $7.60 \pm 1.45$ \\
\hline
\end{tabular}

$\overline{\mathrm{a}, \mathrm{b}}$ Different superscripts in the same column means significant difference at $P<0.05$ level

DON-deoxynivalenol; MDA-malondialdehyde; GSH-reduced glutathione; GSHPx-glutathione peroxidase reflects lipid peroxidation did not change significantly in blood plasma (Table 6), in red blood cell haemolysates it was lower in the DON group compared to control on days 21 and 39 (Table 7), and it was significantly higher in liver homogenate on day 21 but not on day 39 (Table 8).

Reduced glutathione content and glutathione peroxidase activity did not differ significantly as effect of feeding DON contaminated diet either in blood (blood plasma, red blood haemolysates) or in liver homogenate (Tables 6-8).

\section{Discussion}

The results of present trial showed that DON at approximately $1 \mathrm{mg} \cdot \mathrm{kg}^{-1}$ diet did not cause a decrease in the production traits and only slightly modified the concentration of some blood plasma metabolites, mainly during the first phase (day 1 to 21) of the growing period.

This result is in line with previous studies when feeding diets containing feedstuffs naturally contaminated with DON (5 mg $\mathrm{kg}^{-1}$ feed) did not 
Table 8. Effect of diet contaminated with deoxynivalenol on malondialdehyde and reduced glutathione content and glutathione peroxidase activity of liver homogenate (mean \pm SD) of broiler chickens

\begin{tabular}{llcc}
\hline & $\begin{array}{c}\text { MDA } \\
\left(\mu \mathrm{mol} \cdot \mathrm{g}^{-1}\right)\end{array}$ & $\begin{array}{c}\text { GSH } \\
\left(\mathrm{mmol} \cdot \mathrm{g}^{-1} 10,000 \mathrm{~g}\right. \\
\text { supernatant protein })\end{array}$ & $\begin{array}{c}\text { GSHPx } \\
\left(\text { nkat }^{-1} \mathrm{~g}^{-1} 10,000 \mathrm{~g}\right. \\
\text { supernatant protein })\end{array}$ \\
\hline Control & $\begin{array}{c}\text { Day } 21 \\
3.46 \pm 0.85^{\mathrm{a}}\end{array}$ & $2.56 \pm 0.60$ & $47.26 \pm 8.68$ \\
DON & $7.43 \pm 2.70^{\mathrm{b}}$ & $2.34 \pm 0.75$ & $48.76 \pm 6.68$ \\
Control & Day 39 & & \\
DON & $5.26 \pm 1.80$ & $1.82 \pm 0.61$ & $31.90 \pm 6.51$ \\
\hline
\end{tabular}

${ }^{\mathrm{a}, \mathrm{b}}$ Different superscripts in the same column mean significant difference at $P<0.05$ level

DON-deoxynivalenol; MDA-malondialdehyde; GSH-reduced glutathione; GSHPx-glutathione peroxidase have a significant effect on feed consumption, feed conversion, body-weight gain, and live body weight (Hamilton et al. 1985; Awad et al. 2006).

Blood plasma protein concentration did not differ significantly and triglyceride concentration was higher in the DON group on day 21, but lower on day 39, and the uric acid content was lower on day 21, which differs from the findings by Kubena et al. (1988). However, in that trial much higher DON contamination $\left(16 \mathrm{mg} \cdot \mathrm{kg}^{-1}\right.$

feed) was used. Blood plasma glucose content was also significantly lower on day 21 which might be caused by impaired intestinal glucose transport (Aw ad et al. 2004).

Changes of the malondialdehyde content in blood plasma and red blood cell haemolysate and liver homogenate suggest that the potential prooxidant effect of DON did not manifest in blood and the antioxidant system effectively scavenged the free radicals generated by DON in liver homogenate. These results are in agreement with the findings of Borutova et al. (2008) who found that feeding a diet contaminated with DON together with zearalenone at higher concentrations $\left(3.4 \mathrm{mg} \cdot \mathrm{kg}^{-1}\right.$ feed both for DON and zearalenone) resulted in significantly decreased activity of GSHPx and increased MDA in liver.

The significant effect of DON on day 21 was eliminated by day 39 in the case of some biochemical indicators which, according to previous findings, may be caused by the development of intestinal microflora of growing chickens which has detoxifying ability of deoxynivalenol to less toxic de-epoxy metabolites (Young et al. 2007). The amount of absorbed amount of DON therefore possibly gradually decreased with ageing.

\section{Acknowledgement}

The financial support received from the Hungarian Academy of Sciences (Research Group of Animal Breeding and Hygiene) is gratefully acknowledged (2006/TKI/117).

\section{References}

Awad WA, Böhm J, Razzazi-Fazeli E, Hulan HW, Zentek J 2004: Effects of deoxynivalenol on general performance and electrophysiological properties of intestinal mucosa of broiler chickens. Poult Sci 83: 1964-1972

Awad WA, Böhm J, Razzazi-Fazeli E, Zentek J 2006: Effects of feeding deoxynivalenol contaminated wheat on growth performance, organ weights and histological parameters of the intestine of broiler chickens. J Anim Physiol Anim Nutr (Berl) 90: 32-37

Borutova R, Faix S, Placha I, Gresakova L, Cobanova K, Leng L 2008: Effects of deoxynivalenol and zearalenone on oxidative stress and blood phagocytic activity in broilers. Arch Anim Nutr 62: 303-312

Dersjant-Li YM, Verstegen MWA, Gerrits WJJ 2003: The impact of low concentrations of aflatoxin, deoxynivalenol or fumonisin in diets on growing pigs and poultry. Nutr Res Rev 16: 223-239

Eriksen GS, Pettersson H 2004: Toxicological evaluation of trichothecenes in animal feed. Anim Feed Sci Technol 114: $205-239$

EU 2005: Council Directive 2005/38/EC - laying down the sampling methods and the methods of analysis for the official control of the levels of Fusarium toxins in foodstuffs. Off J European Union L 143/52: $18-19$ 
EU 2006: Commission Recommendation 2006/576/EC on the presence of deoxynivalenol, zearalenone, ochratoxin A, T-2 and HT-2 and fumonisins in products intended for animal feeding. Off J European Union L 229/7: 1-2

Faixova Z, Faix S, Leng L, Vaczi F 2006: Protective effect of selenium in mycotoxin toxicity. In: Zbornik z medzinarodnej vedeckej konferencie "Risk factors of food chain", Nitra, pp. 79-83

Hamilton RM, Trenholm HL, Thompson BK, Greenhalgh R 1985: The tolerance of White Leghorn and broiler chicks, and turkey poults to diets that contained deoxynivalenol (vomitoxin)-contaminated wheat. Poult Sci 64: $273-286$

Hungarian Feed Code 2004a: Nutrient requirements of poultry (In Hungarian). Vol II. pp. 65-67. OMMI, Budapest

Hungarian Feed Code 2004b: Methods of determination of nutrients in animal feeding stuffs (In Hungarian). Vol. III. pp. 101-129. OMMI, Budapest

Jelinek CF, Ponland AE, Wood GE 1989: World wide occurrence of mycotoxins in foods and feeds - an update. J AOAC 72: 223-230

Kubena LF, Harvey RB, Corrier DE, Huff WE 1987: Effects of feeding deoxynivalenol (DON, vomitoxin)contaminated wheat to female White Leghorn chickens from day old through egg production. Poult Sci 66: 1612-1618

Kubena LF, Huff WE, Harvey RB, Corrier DE, Phillips TD, Creger CR. 1988: Influence of ochratoxin A and deoxynivalenol on growing broiler chicks. Poult Sci 67: 253-260

Lawrence RA, Burk RF 1976: Glutathione peroxidase activity in selenium deficient rat liver. Biochem Biophys Res Commun 71: 952-956

Leeson S, Diaz G, Summers JD 1995: Poultry metabolic disorders and mycotoxins. University Books, Guelph, pp. 190-226

Levkut M, Revajová V, Levkutova M, Sevcíková Z, Herich R, Borutová R, Leng L 2009: Leukocytic responses of broilers following dietary contamination with deoxynivalenol and/or treatment by dietary selenium supplementation. Br Poult Sci 50: 181-187

Lowry OH, Rosenbrough NJ, Farr AL, Randall RJ 1951: Protein measurement with the Folin phenol reagent. J Biol Chem 193: 265-275

Mihara M, Uchiyama M, Fukuzawa K 1980: Thiobarbituric acid value of fresh homogenate of rat as parameter of lipid peroxidation in ageing, $\mathrm{CCl}_{4}$ intoxication and vitamin $\mathrm{E}$ deficiency. Biochem Med 23: 302-311

Placer ZA, Cushman LL, Johnson BC 1966: Estimation of product of lipid peroxidation (malonyl dialdehyde) in biochemical systems. Anal Biochem 16: 359-364

Sedlak I, Lindsay RH 1968: Estimation of total, protein-bound and non-protein sulfhydryl groups in tissues with Ellmann's reagent. Anal Biochem 25: 192-205

Surai PF 2002: Natural antioxidants in avian nutrition and reproduction. Nottingham University Press, Nottingham, pp. 455-510

Young JC, Zhou T, Yu H, Zhu H, Gong J 2007: Degradation of trichothecene mycotoxins by chicken intestinal microbes. Food Chem Toxicol 45: 136-143

Weber M, Balogh K, Fodor J, Erdélyi M, Ancsin Zs, Mézes M 2010: Effect of T-2 and HT-2 toxin during the growing period on body weight, lipid peroxide and glutathione redox status of broiler chickens. Acta Vet Brno 79: $27-31$

Weichselbaum TE 1948: An accurate and rapid method for the determination of protein in small amounts of serum and plasma. Am J Clin Pathol 16: 40-43 